\title{
Good Governance dalam Pemerintah Daerah
}

\author{
NOVERMAN DUADJ I \\ Administrasi Negara FISIP Universitas Lampung, JI. Sumantri Brojonegoro No.1 \\ Bandar Lampung 35144 \\ e-mail: novermanduadji@yahoo.co.id
}

\begin{abstract}
The Governance is the frame to reform the government ideology, paradigm, culture and management. Such as a response action from the government that have made some policies as legal formal action. For reaching the good governance and the government highest performance, so tree of governance principal: accountability, transparency and participation must operate better by the real action that called the revitalization. It is injection the good governance values to public business that has a legal formal policy.
\end{abstract}

Keyword: Governance, Government Performance, Accountabillity

\begin{abstract}
Abstrak. Governance merupakan kerangka konsep untuk membenahi ideologi, paradigma, kultur dan manajemen kepemerintahan agar memiliki kinerja tinggi. Merespon hal ini, Pemerintah telah mengeluarkan beberapa kebijakan sebagai landasan legal formal, mulai dari Kebijakan Akuntabilitas Kinerja Pemerintah sampai dengan Kebijakan Anggaran Berbasis Kinerja. Dalam rangka mencapai good governance, guna menuju kinerja pemerintahan yang tinggi, maka 3 pilar good governance: akuntabilitas (accountability), transparansi (transparency), dan partisipasi (participation) haruslah diimplementasikan dengan baik melalui tindakan nyata dalam bentuk revitalisasi, yaitu penginjeksian nilai-nilai good governance dalam praktekpraktek penyelenggaraan urusan publik dengan landasan legal formal.
\end{abstract}

Kata Kunci: Tata Kelola, Kinerja Pemerintah, Akuntabilitas

\section{Pendahuluan}

Governance merupakan kerangka konsep 'filosofis', 'teoritis' dan 'analitis' yang sangat berguna sebagai landasan untuk membenahi idiologi, paradigma, kultur dan manajemen kepemerintahan (manajemen publik). Konsep governance ini bukan hanya ditujukan sebatas orientasi internal organisatoris, melainkan juga pada aspek eksternal, output, outcome dan impact, yaitu upaya mewujudkan kemakmuran yang berkeadilan dan adil berkemakmuran bagi rakyatnya sebagai parameter dari penyelenggaraan pemerintahan yang memiliki kinerja tinggi. Disamping itu pula gagasan ini tentu juga bersinggungan dengan keinginan untuk meningkatkan daya saing dan inovasi aparatur publik baik di tingkat lokal, nasional maupun di tingkat global.

Tulisan ini merupakan refleksi fakta (persoalan) problem implementasi kebijakan good governance pada level Pemerintah Daerah dan akan mencoba memberikan gagasan tentang solusi menuju good governance melalui penerapan prinsip-prinsip good governance. Adapun yang menjadi obyek penelitian adalah APBD Kabupaten
Lahat yang ditelaah dari sisi postur dan alokasinya. Adapun yang menjadi dasar pertimbangan pemilihan lokasi penelitian adalah: (1) Kabupaten Lahat sebagai Kabupaten Induk yang sudah dimekarkan menjadi 3 Daerah Otonom Baru (OTB) sehingga peneliti menduga pengelolaan APBD-nya sudah relatif baik; (2) Sebagai Kabupaten Induk, geliat ekonomi dan pemberdayaan masyarakat Kabupaten Lahat bukan dampak langsung dari program layanan publik dan pembangunan yang didanai oleh $A P B D$, tetapi terdorong oleh pesatnya kawasan industri pertambangan dan perkebunan melalui dana-dana CSR dan kemitraan. Tujuan penelitian adalah untuk menemukan postur dan performa alokasi APBD Kabupaten Lahat serta merumuskan konsep penyempurnaannya.

Sehubungan dengan hal tersebut, maka artikel ini mengetengahkan bentuk analisis dengan menggunakan metode penelusuran dan pengkajian pustaka (studi pustaka), baik tentang dokumen kebijakan operasional maupun mengenai landasan konsep dan teori dari beberapa sumber referensi serta diikuti dengan wawancara dengan satker terkait sebagai informan dan dijadikan landasan cross-check atas dokumen-dokumen.

Pada bagian ini akan diketengahkan tentang 
problem implementasi governance dalam pemerintah daerah berdasarkan telaah kebijakan sebagai landasan legal formal dan kebijakan operasional.

Bila ditinjau secara substantif konseptual UU No. 22 tahun 1999 yang direvisi UU No. 32 tahun 2004 tentang Pemerintahan Daerah, ada beberapa hal mendasar dari nilai-nilai konseptual yang ingin diterapkan dan sekaligus ingin dicapai oleh kedua paket kebijakan itu. Dwiyanto (2003:25) mengemukakan "nilai-nilai konseptual itu terdiri dari: (1) merubah nilai-nilai otokratis sentralistis dan hirarkis menjadi domokratis desentralistis yang fungsional dalam penyelenggaraan dan interaksi antar lembaga kepemerintahan; (2) meretas nilai birokratis feodalistis sebagai warisan negara administrasi kearah tumbuh-kembangnya nilai administrasi partisipatif, responsif dan adaptif akan kepentingan masyarakat; (3) mengganti nilai konsumtif dan menghambur-hamburkan anggaran kearah pertimbangan prioritas dan jiwa wirausaha (entrepreneurship); (4) merubah perilaku aktor kepemerintahan yang berjiwa ingin mendapatkan pelayanan menjadi abdi, pelayan dan fasilitator masyarakat; (5) merubah ketergantungan akan sumber daya dari pusat dengan mengembangkan otonomi (kemandirian), keberdayaan dan kesetaraan yang bertanggungjawab (akuntabilitas); dan (6) menumbuhkembangkan dan tegaknya prinsip check and balance, equity dan equality antar komponen governance.

Upaya merespon dan sekaligus memanfaatkan konsep tersebut diatas, maka kehadiran UU No. 22 tahun 1999 yang direvisi UU No. 32 tahun 2004 tentang Pemerintahan Daerah, khususnya dalam praktek penyelenggaraan pemerintahan lokal (Kabupaten/Kota) mulai memaksimalkan peran dan bahkan berlombalomba untuk menjadi pionir perencana dan distribusi dana APBD kearah implementasi nilainilai kepemerintahan yang berjiwa wirausaha (en- trepreneurship governance) sebagai pengejawantahan good governance. Namun sangat disayangkan, apabila dicermati pada aras implementatif, kondisi manajemen pemerintah dan penyelenggaraan birokrasi publik masih banyak kelemahannya. Penetapan kedisiplinan, penghematan, budaya kerja, kualitas pelayanan, netralitas birokrasi, sampai dengan penerbitan berbagai peraturan perundang-undangan pendukung atau dengan kata lain aspek restrukturisasi dan revitalisasi masih kental memperlihatkan wajah buramnya. Peningkatan kualitas kinerja aparatur dan pelayanan publik masih jauh dari harapan dan keinginan masyarakat, pemborosan yang masih juga belum dapat diperbaiki, korupsi yang masih merajalela, tarikan kuat yang dilakukan oleh pejabat politik terhadap pejabat birokrasi, merupakan citra yang menggangu kinerja birokrasi pemerintah.

Uraian diatas memiliki keterkaitan dengan penjelasan dari Surkati (2012) dengan topik Otonomi Daerah Sebagai Instrumen Pertumbuhan Kesejahteraan dan Peningkatan Kerjasama Antar Daerah yang menyatakan bahwa "otonomi daerah dalam Peraturan Perundang-undangan dari segi penyelenggaraan pemerintahannya tidak terlepas dengan proses penerapan Azas Desentralisasi, Azas Dekonsentrasi dan Tugas Pembantuan (Medebewind). Undang-Undang dasar 1945 pasal 18, 18 A dan $B$, dimana pembagian daerah ini diberikan hak otonomi untuk mengurusi rumah tangganya sendiri. Pembagian daerah akan berkaitan dengan geografi dan potensi di wilayahnya masing-masing yang tidak berimbang. Penerapan azas otonomi daerah dalam rangka menjaga Negara Kesatuan Republik Indonesia antara pemerintahan pusat dan pemerintahan daerah. Oleh karena itu persoalannya adalah bagaimana penerapan azas otonomi daerah dapat meningkatkan kesejahteraan dan kerjasama antar daerah secara nasional dengan kondisi potensi

Tabel 1

Alokasi (Proporsi) APBD Kabupaten Lahat Tahun 2009-2012

\begin{tabular}{|c|c|c|c|}
\hline \multirow{2}{*}{ No } & \multirow{2}{*}{ Tahun } & \multicolumn{2}{|c|}{ Alokasi (Proporsi) APBD } \\
\cline { 3 - 4 } & & $\begin{array}{c}\text { Anggaran Rutin } \\
\text { \& Belanja Pegawai (\%) }\end{array}$ & $\begin{array}{c}\text { Anggaran Layanan Publik } \\
\text { dan Pembangunan(\%) }\end{array}$ \\
\hline 1 & 2009 & 80 & 20 \\
2 & 2010 & 75 & 25 \\
3 & 2011 & 70 & 30 \\
4 & 2012 & 70 & 30 \\
\hline
\end{tabular}

Sumber: Dokumen APBD Kabupaten Lahat Tahun 2009-2012 
wilayah yang tidak berimbang seperti keadaan geografi dan sumber daya manusianya".

Mengacu pada uraian Surkati (2012) tersebut diatas, maka sesungguhnya yang menjadi titik tekan adalah perbaikan dan peningkatan kualitas pengelolaan anggaran instansi pemerintah atau yang lazim dikenal dengan istilah pengelolaan anggaran berbasis kinerja (performance budgeting). Artinya setiap perencanaan pengalokasian (distribusi) anggaran harus disesuaikan dengan skala prioritas untuk pencapaian tujuan, yaitu peningkatan dan percepatan kesejahteraan masyarakat. Postur performance budgeting ini tampak jelas pada persentase alokasi anggaran (APBD) harus lebih besar proporsinya bagi upaya pembiayaan layanan publik dan pembangunan bagi masyarakat di daerah. Namun sayangnya dalam praktek penganggaran (alokasi APBD) pada kebanyakan propinsi, kabupaten dan kota di Indonesia masih lebih besar proporsi belanja rutin dan belanja pegawai ketimbang alokasi dana untuk layanan publik dan pembangunan masyarakat.

Sehubungan dengan tulisan ini menyoroti APBD Kabupaten Lahat Provinsi Sumatera Selatan, maka untuk memberikan gambaran singkat akan disajikan proporsi alokasi APBD Kabupaten Lahat seperti terlihat pada Tabel 1 .

Kendati hampir semua satker anggaran (Dinas dan Badan) Kabupaten Lahat menjelaskan kepada peneliti bahwa APBD sudah disusun berdasarkan kinerja dinas dan badan serta secara langsung menyentuh kebutuhan layanan publik dan pembangunan, namun dari Tabel 1 dapat dijelaskan bahwa alokasi (proporsi) APBD Kabupaten Lahat belum disusun berdasarkan performance budgeting (anggaran berbasis kinerja) dimana masih didapati persentease anggaran rutin dan belanja pegawai masih lebih besar ketimbang anggaran layanan publik dan pembangunan. Bahkan jika ditelusuri lebih seksama usulan-usulan program yang diajukan masing-masing dinas dan badan masih berlombalomba kepada pengejaran target internal organisasi (kepentingan dan kebutuhan dinas dan badan). Hal ini mengindikasikan anggaran yang disusun belum mampu secara optimal dimanfaatkan bagi pemberdayaan ekonomi dan peningkatan kesejahteraan masyarakat. Perspektif demikian juga berkaitan dengan nilai teologi seperti statemen Muhardi (2005) dengan topik 'paradigma boros dalam kegiatan ekonomi' yang menyatakan bahwa "Kegiatan ekonomi (economic activity) sesungguhnya sudah ada semenjak kehadiran manusia di muka bumi ini. Demikian pula dengan aktivitas ekonomi tersebut akan terus berlangsung selama manusia di muka bumi ini ada. Dalam rangka memenuhi kebutuhan hidup atau ekonominya tersebut, manusia atau sebuah keluarga dihadapkan pada berbagai pilihan atau alternatif tindakan dan cara-cara yang ditempuhnya. Tindakan dan cara yang bagaimana yang akan diambilnya akan sangat ditentukan dan dipengaruhi oleh sejauhmana nilai-nilai yang diyakini seseorang tertanam dalam dirinya. Sikap berlebih-lebihan dalam memenuhi kebutuhan hidup bukanlah tindakan yang baik, karena cara tersebut tidak sesuai dengan prinsip ekonomi yang benar dan juga syariah I slam. Agama Islam telah mengajarkan bagaimana memenuhi kebutuhan ekonomi secara seimbang atau layak, dalam arti tidak berlebih-lebihan (israf)". Kutipan ini mempertegas bahwa paradigma pengelolaan anggaran (APBD) masih terkontaminasi nilai-nilai pemborosan, belum mengarah pada efektifitas dan efisiensi pengelolaan APBD yang semestinya perlu dilandasi nilai moral dan etika aparatur publiknya dalam kerangka akhir akuntabilitas publik, baik pada domain akuntabilitas organisasi maupun pada ranah akuntabilitas kepada rakyat sebagai subyek layanan publik dan pembangunan itu sendiri.

Dalam penyelenggaraan layanan publik dan pembangunan di Kabupaten Lahat ternyata ada

Tabel 2

Rasio Alokasi (Proporsi) APBD Kabupaten Lahat dengan Dana CSR untuk Layanan Publik dan Pembangunan Tahun 2009-2012

\begin{tabular}{|c|c|c|c|}
\hline \multirow{2}{*}{ No } & \multirow{2}{*}{ Tahun } & \multicolumn{3}{|c|}{ Rasio } \\
\cline { 3 - 4 } & & $\begin{array}{c}|c| \\
\text { APBD untuk Anggaran } \\
\text { Layanan Publik dan Pembangunan (\%) }\end{array}$ & $\begin{array}{c}\text { CSR untuk Layanan } \\
\text { Publik dan Pembangunan (\%) }\end{array}$ \\
\hline 1 & 2009 & 95 & 5 \\
2 & 2010 & 90 & 10 \\
3 & 2011 & 80 & 20 \\
4 & 2012 & 50 & 50 \\
\hline
\end{tabular}

Sumber: Laporan Bappeda Kabupaten Lahat Tahun 2009-2012 
kontribusi dana CSR dari industri pertambangan dan perkebunan yang cukup signifikan, baik dari sisi jumlah maupun peningkatan rasio (proporsi) CSR seperti terlihat pada Tabel 2. Hal ini mengindikasikan bahwa peningkatan kualitas layanan publik dan geliat ekonomi (pemberdayaan ekonomi) masyarakat lebih banyak didorong oleh program-program yang didanai oleh CRS industri pertambangan dan perkebunan. Sementara APBD masih dominan digunakan untuk membiayai kegiatan internal institusi pemerintah (belanja rutin dan belanja pegawai).

Untuk memperbaiki dan meningkatkan kinerja instansi pemerintah, maka pemerintah mengeluarkan beberapa paket kebijakan sebagai landasan legal formal. Pertama, terbitnya Inpres No 7 Tahun 1999 merupakan salah satu upaya pemerintah untuk meningkatkan pelaksanaan pemerintahan (birokrasi publik) yang lebih berdaya guna, berhasil guna, bersih dan bertanggung jawab (akuntabel). Kemudian Keputusan Lembaga Administrasi Negara Nomor 589/IX/6/Y/99 yang kemudian disempurnakan dengan Keputusan Lembaga Administrasi Negara Nomor 239//X/6/8/ 2003 yang sebagai landasaran tentang perlunya Laporan Akuntabilitas Kinerja Instansi Pemerintah (LAKIP) sebagai capaian kinerja (cerminan visi dan misi organisasi). Kedua, difokuskan melalui perbaikan manajemen keuangan negara. Pemerintah mengeluarkan kebijakan berupa Instruksi Presiden No. 5 Tahun 2004 tentang Percepatan Pemberantasan Korupsi. Upaya lainnya untuk memperkokoh dan mendorong langkah reformasi manajemen keuangan negara, adalah telah disusun dan diberlakukannya paket perundang-undangan bidang keuangan negara, yaitu: a) Undang-undang Nomor 17 Tahun 2003 tentang Keuangan Negara; b) Undang-undang Nomor 1 Tahun 2004 tentang Perbendaharaan Negara, dan c) Undang-undang Nomor 15 Tahun 2004 tentang Pemeriksaan Pengelolaan dan Tanggung J awab Keuangan Negara. Perubahan mendasar diterbitkannya 3 (tiga) paket UndangUndang tersebut adalah penerapan sistem anggaran berbasis kinerja (performance based budgeting) dalam pengelolaan keuangan negara dan juga termasuk didalamnya mulai dari penerapan perencanaan kinerja, pertanggungjawaban dan pengelolaan kinerja, evaluasi kinerja serta diberlakukan pemeriksaan (audit) kinerja. Ketiga, selanjutnya terbit pula Undang-Undang No 25 Tahun 2004 tentang Sistem Perencanaan Pembangunan Nasional yang mengatur dari aspek perencanaan, yang juga menekankan manajemen berbasis kinerja dalam setiap perencanaan pembangunan dan kegiatan dalam lingkungan instansi pemerintah baik pusat maupun daerah.

Dalam konteks penyelenggaraan pemerintah daerah, juga tidak lepas dari penerapan anggaran berbasis kinerja tersebut dalam setiap penyusunan rencana kerja dan anggaran sebagaimana disebutkan dalam Pasal 19 UU No 17 Tahun 2003. Dalam rangka mendukung terwujudnya good governance dalam penyelenggaraan negara, pengelolaan keuangan negara perlu diselenggarakan secara profesional, terbuka, dan bertanggung jawab sesuai dengan aturan pokok yang telah ditetapkan dalam Undang-Undang Dasar (UUD). Sesuai dengan amanat Pasal 23C UUD 1945, dalam UU No 17 tahun 2003 tentang Keuangan Negara menjabarkan aturan pokok yang telah ditetapkan dalam UUD tersebut ke dalam asas-asas umum yang meliputi baik asas-asas yang telah lama dikenal dalam pengelolaan keuangan negara, seperti asas tahunan, asas universalitas, asas kesatuan, dan asas spesialitas, maupun asasasas baru sebagai pencerminan best practices (penerapan kaidah-kaidah yang baik) dalam pengelolaan keuangan negara, antara lain; akuntabilitas berorientasi pada hasil, profesionalitas, proporsionalitas, keterbukaan dalam pengelolaan keuangan negara, dan pemeriksaan keuangan oleh badan pemeriksa yang bebas dan mandiri.

Penerapan anggaran berbasis prestasi/hasil kerja dimaksudkan sebagai upaya memperbaiki proses penganggaran di sektor publik. Mengingat bahwa sistem anggaran berbasis prestasi kerja/ hasil memerlukan kriteria pengendalian kinerja dan evaluasi serta untuk menghindari duplikasi dalam penyusunan rencana kerja dan anggaran kementerian negara/lembaga/perangkat daerah, perlu dilakukan penyatuan sistem akuntabilitas kinerja dalam sistem penganggaran dengan memperkenalkan sistem penyusunan rencana kerja dan anggaran kementerian negara/lembaga/ perangkat daerah. Dengan penyusunan rencana kerja dan anggaran kementerian/lembaga/ perangkat daerah tersebut dapat terpenuhi sekaligus kebutuhan akan anggaran berbasis prestasi kinerja dan pengukuran akuntabilitas kinerja kementerian/lembaga/perangkat daerah yang bersangkutan. Penerapan anggaran berbasis kinerja diperlukan untuk menegakkan kinerja organisasi instansi pemerintah, sekaligus sebagai dasar untuk meninjau kembali program/kegiatan yang tidak berhasil mencapai target.

Mencermati hasil audit BPKP, pemeriksaan inspektorat daerah maupun hasil pengawasan yang dilakukan lembaga legislatif daerah (DPRD), pengalokasian dana APBD Kabupaten Lahat dari tahun 2009-2012 tidak diketemukan penyimpangan yang berarti. Artinya secara legal formal tidak diketemukan indikasi terjadinya tindak pidana (korupsi) APBD Kabupaten Lahat. Hanya ada 2 kasus tindak pidana korupsi yang dilakukan oleh oknum Kepala Desa yang menggunakan dana Pro- 
gram Nasional Pemberdayaan Masyarakat (PNPM) Mandiri yang sumber dananya dari dana sharing Pemerintah Pusat (APBN) dan APBD Kabupaten.

Deskripsi diatas hanya mencerminkan bahwa pengalokasian dana APBD sudah memenuhi prosedur operasional baku (standard operating procedure) atau tidak menyalahi tata cara dan aturan yang telah ditentukan. Kendati demikian, jika ditinjau dari konteks pencapaian tujuan penyelenggaraan urusan layanan publik dan pembangunan bahwa alokasi dana APBD belum mampu mencapai sasaran off target. Semestinya, orientasi konseptual performance budgeting (anggaran berbasis kinerja) adalah lebih bermuara pada peningkatan kualitas layanan publik dan pembangunan, sehingga pada masa tertentu terjadi akselerasi dan peningkatan kesejahteraan masyarakat yang bermukim pada suatu wilayah kabupaten bahkan menjadi katalisator kemajuan ekonomi dan pemberdayaan masyarakat antar daerah. Disamping itu, penerapan performance budgeting (anggaran kinerja) perlu juga mempertimbangkan dimensi entrepreneurship pemerintah kabupaten, yaitu investasi yang dikeluarkan dapat menambah jumlah dan sumber pendapatan baru bagi pemerintah kabupaten, karena anggaran berbasis kinerja itu memiliki arti penting atas keunggulan-keunggulan yang dimiliki. Sebagaimana diketahui bahwa secara konseptual, "penerapan penganggaran berbasis kinerja memiliki keunggulan tidak saja mendorong terciptanya transparansi dan akuntabilitas publik, tetapi juga mendorong pengambilan keputusan dan penyusunan prioritas anggaran yang lebih baik, termasuk pengawasan dan pengendalian ke arah outcomes (World Bank, 1989 dan 1992).

Anggaran berbasis kinerja juga lebih fleksibel dalam artian dimungkinkannya pergeseran anggaran dari satu jenis belanja ke belanja lain sepanjang berada dalam lingkup sasaran stratejik yang sama. Adanya fleksibilitas akan dapat meningkatkan keekonomisan dan efisiensi. Selanjutnya adanya keterkaitan antara sasaran stratejik dengan alokasi dana akan lebih memudahkan perencanaan, pelaksanaan, evaluasi yang bersifat menyeluruh, baik dari segi pencapaian sasaran, perumusan dan implementasi program/kegiatan, maupun proses penetapan dan pengendalian anggaran dan analisis kinerja. Selanjutnya dalam konteks mewujudkan pemerintah yang kredibel (high perfoming govemment), penerapan anggaran berbasis kinerja dapat dikategorikan sebagai bagian atau salah satu elemen dari managing for results atau performance management (World Bank, 1992:35).

Selanjutnya sebagai pelaksanaan UU No 1 Tahun 2004, pemerintah telah menerbitkan Peraturan Pemerintah No 8 tahun 2006 tentang Pelaporan Keuangan dan Kinerja Instansi
Pemerintah. Dengan adanya PP tersebut, pertanggungjawaban pelaksanaan anggaran negara (APBN/APBD) tidak hanya pada laporan keuangan saja, yakni laporan realisasi anggaran, Neraca, Laporan Arus Kas dan catatan atas Laporan Keuangan, namun terdapat pula kewajiban untuk menyampaikan informasi mengenai kinerja instansi pemerintah, yakni prestasi yang berhasil dicapai oleh pengguna anggaran sehubungan dengan anggaran yang telah digunakan. Namun demikian perlu ditegaskan pula bahwa pemahaman kinerja instansi pemerintah tidak dapat semata hanya diukur dari pencapaian atau penyerapan penggunaan anggaran negara (APBN/APBD). Akan tetapi harus dapat diukur pula prestasi kerja secara keseluruhan dalam suatu unit organisasi atau instansi pemerintah tersebut khususnya dalam menjalankan tugas pokok dan fungsinya. Dari penggunaan anggaran negara tersebut harus memperlihatkan pula apakah menunjukkan tingkat pencapaian sasaran dan tujuan yang telah ditetapkan, dan apakah berorientasi pada pencapaian visi dan misi, serta hasil dan manfaat yang diperoleh.

Dalam Bagian Penjelasan atas PP No. 8 tersebut diuraikan bahwa pengungkapan informasi tentang kinerja ini adalah relevan dengan perubahan paradigma penganggaran pemerintah yang ditetapkan dengan mengidentifikasikan secara jelas keluaran (output) dari setiap kegiatan dan hasil (outcomes) dari setiap program. Untuk keperluan tersebut, perlu disusun suatu sistem akuntabilitas kinerja instansi pemerintah yang terintegrasi dengan sistem perencanaan strategis, sistem penganggaran, dan sistem akuntansi pemerintahan. Dari sisi pemeriksaan atau audit kinerja, maka dengan terbitnya UU No. 15 tahun 2004 membawa perubahan sangat mendasar dalam manajemen keuangan negara, diantaranya adalah menegaskan posisi Badan Pemeriksa Keuangan (BPK) selaku auditor eksternal yang akan melakukan audit atas seluruh penyelenggaraan negara yang berimplikasi pada pembiayaan dan anggaran negara. Pasal 2 dan pasal 4, menyebutkan bahwa BPK melaksanakan pemeriksaan atas pengelolaan dan tanggung jawab keuangan negara, yang terdiri atas pemeriksaan keuangan, pemeriksaan kinerja, dan pemeriksaan dengan tujuan tertentu, yang memuat hal-hal: (a) Pemeriksaan Keuangan adalah pemeriksaan atas laporan keuangan; (b) Pemeriksaan Kinerja adalah pemeriksaan atas pengelolaan keuangan negara yang terdiri atas pemeriksaan aspek ekonomi dan efisiensi serta pemeriksaan aspek efektivitas; (c) Pemeriksaan dengan tujuan tertentu, misalnya permintaan pihakpihak berwewenang untuk menindaklanjuti indikasi distorsi atau korupsi anggaran. Kesemuanya itu sebagai manifestasi dari Pasal 23E Undang-Undang 
Dasar Negara Republik I ndonesia Tahun 1945 yang mengamanatkan BPK untuk melaksanakan pemeriksaan kinerja pengelolaan keuangan negara. Tujuan pemeriksaan ini adalah untuk mengidentifikasikan hal-hal yang perlu menjadi perhatian lembaga perwakilan rakyat (DPR/DRPD). Adapun untuk pemerintah, pemeriksaan kinerja dimaksudkan agar kegiatan yang dibiayai dengan keuangan negara/daerah diselenggarakan secara ekonomis dan efisien serta memenuhi sasarannya secara efektif. Dengan adanya penegasan mandat untuk melakukan pemeriksaan, maka instansi pemerintah dituntut membuat pertanggungjawaban atas seluruh penyelenggaraan kebijakan/ program/kegiatan yang berimplikasi pada penggunaan keuangan negara.

Substansi dari reformasi dalam bidang keuangan negara terutama dari sisi akuntabilitas atas penggunaan keuangan negara sebagaimana termaktub dalam UU No 15 Tahun 2004 tentang Pemeriksaan Pengelolaan dan Tanggung Jawab Keuangan Negara memuat 2 (dua) dasar pertimbangan. Pertama, untuk mendukung kebérhasilan penyelenggaraan pemerintahan negara, keuangan negara wajib dikelola secara tertib, taat pada peraturan perundang-undangan, efisien, ekonomis, efektif, transparan, dan bertanggung jawab dengan memperhatikan rasa keadilan dan kepatutan. Kedua, untuk mewujudkan pengelolaan keuangan negara, perlu dilakukan pemeriksaan berdasarkan standar pemeriksaan oleh Badan Pemeriksa Keuangan yang bebas dan mandiri.

Dalam kaitannya dengan budgeting policy pada level pemerintahan daerah, penegasan Presiden tersebut mengingatkan pada beberapa hal pokok. Pertama, perlu adanya reformasi manajemen publik untuk mewujudkan good governance yang bercirikan antara lain: bersih, produktif, efisien, tanggap, responsif, terbuka atau transparan, akuntabel, dan harus lebih banyak bekerja daripada bicara (do more talk less). Kedua, melakukan upaya pemberantasan korupsi mulai sekarang dimulai dari diri sendiri dan lingkungan tempat kerja masing-masing, menghilangkan niat dan kesempatan untuk melakukan korupsi disertai peningkatan kesejahteraan bagi aparatur negara. Ketiga, memberikan pelayanan publik yang konkrit, aplikatif, cepat, tepat, mudah, murah, makin baik, terus menerus meningkat dan tidak diskriminatif kearah peningkatan kualitas pelayanan publik. Keempat, membuka ruang yang seluas-luasnya untuk menumbuh-kembangkan dan mempupuk terciptanya partisipasi publik dalam penyelenggaraan tatanan kepemerintahan. Kelima, keterbukaan akses informasi (transparansi) penyelenggaraan tatanan kepemerintahan sehingga mekanisme check and bacance inter dan intra institusi governance akan berjalan sebagai upaya mengeliminir terjadinya tindakan distortif dan korup.

Dari sekelumit uraian di atas, maka hal pokok yang menarik fokus perhatian adalah terjadinya kontradiksi penyelenggaraan tatanan kepemerintahan artinya diketemukan adanya kesenjangan. Pada konteks atau domain teori sudah terjadi reformasi dalam segala aspek; tetapi pada aras praktek, reformasi yang berimplikasi pada fleksibelitas, inovasi, partisipasi, dan enterpreneurship pengelolaan anggaran justru dimanfaatkan dan peluang baru bagi para elit birokrasi dan privat kearah perilaku distortif, korup dan tidak akuntabel. Dengan kata lain, perangkat peraturan tentang anggaran berbasis kinerja ini masih menimbulkan terjadinya ekses-ekses dan pola-pola penghaluskan tindakan perilaku korup aparatur publik yang sangat menyengsarakan dan memarjinalisasikan masyarakat, baik secara ekonomi (kemakmuran) maupun secara politik, yaitu masyarakat dijauhkan akses partisipasinya mulai dari proses perumusan, pelaksanaan dan evaluasi pengalokasian APBD untuk membiayai program-program tertentu. Oleh karenanya, penulis memandang bahwa korupsi sebagai 'extra ordinary crimes' (kejahatan luar biasa) yang juga biasa disebut kejahatan kerah putih (white collar crime) karena umumnya tindakan ini dilakukan oleh orang-orang terdidik dan terhormat yang memiliki kedudukan penting baik di lingkungan penyelenggara negara maupun di lingkungan pengusaha dan profesional dengan suatu akibat matinya hak-hak asasi/dasar (hak hidup, ekonomi, sosial dan politik) warga negara.

\section{Analisis}

Governance, yang diterjemahkan menjadi tata pemerintahan adalah 'penggunaan wewenang ekonomi, politik dan administrasi guna mengelola urusan-urusan negara pada semua tingkat' (Dwiyanto, 2003: 45). Tata pemerintahan mencakup seluruh mekanisme, proses dan lembaga-lembaga dimana warga dan kelompokkelompok masyarakat mengutarakan kepentingan mereka,menggunakan hak hukum, memenuhi kewajiban dan menjembatani perbedaanperbedaan diantara mereka. Lebih lanjut, disebutkan bahwa dalam konteks pembangunan, definisi governance adalah mekanisme pengelolaan sumber daya ekonomi dan sosial untuk tujuan pembangunan, sehingga good governance, dengan demikian, adalah mekanisme pengelolaan sumber daya ekonomi dan social yang substansial dan penerapannya untuk menunjang pembangunan yang stabil dengan syarat utama efisien dan relatif merata. Menurut dokumen UNDP seperti dikutif Dwiyanto (2003:49), 'tata 
pemerintahan adalah penggunaan wewenang ekonomi politik dan administrasi guna mengelola urusan-urusan negra pada semua tingkat. Tata pemerintahan mencakup seluruh mekanisme, proses dan lembaga-lembaga dimana warga dan kelompok-kelompok masyarakat mengutarakan kepentingan mereka, menggunakan hak hukum, memenuhi kewajiban dan menjembatani perbedaan-perbedaan diantara mereka.' Jelas bahwa good governance adalah masalah perimbangan antara negara, pasar dan masyarakat.

Membangun good governance adalah mengubah cara kerja state, membuat pemerintah accountable, dan membangun pelaku-pelaku di luar negara cakap untuk ikut berperan membuat sistem baru yang bermanfaat secara umum. Dalam konteks ini, tidak ada satu tujuan pembangunan yang dapat diwujudkan dengan baik hanya dengan mengubah karakteristik dan cara kerja institusi negara dan pemerintah. Harus kita ingat, untuk mengakomodasi keragaman, good governance juga harus menjangkau berbagai tingkat wilayah politik. Karena itu, membangun good governance adalah proyek sosial yang besar. Agar realistis, usaha tersebut harus dilakukan secara bertahap. Untuk Indonesia, fleksibilitas dalam memahami konsep ini diperlukan agar dapat menangani realitas yang ada.

UNDP merekomendasikan beberapa karakteristik governance, yaitu legitimasi politik, kerjasama dengan institusi masyarakat sipil, kebebasan berasosiasi dan berpartisipasi, akuntabilitas birokratis dan keuangan (financial), manajemen sektor publik yang efisien, kebebasan informasi dan ekspresi, sistem yudisial yang adil dan dapat dipercaya. Sedangkan World Bank mengungkapkan sejumlah karakteristik good governance adalah masyarakat sipil yang kuat dan partisipatoris, terbuka, pembuatan kebijakan yang dapat diprediksi, eksekutif yang bertanggung jawab, birokrasi yang profesional dan aturan hukum. Masyarakat Transparansi Indonesia menyebutkan sejumlah indikator seperti: transparansi, akuntabilitas, kewajaran dan kesetaraan, serta kesinambungan. Asian Development Bank sendiri menegaskan adanya konsensus umum bahwa 'good governance dilandasi oleh 4 pilar yaitu (1) accountability, (2) transparency, (3) predictability dan (4) participation' (Dwiyanto, 2003: 52).

Berikut ini adalah pembahasan mendalam dari ketiga prinsip tersebut. Akuntabilitas menjadi kunci dari semua prinsip dari governance. Prinsip ini menuntut dua hal yaitu (1) kemampuan menjawab (answerability), dan (2) konsekuensi (consequences). Komponen pertama (istilah yang bermula dari responsibilitas) adalah berhubungan dengan tuntutan bagi para aparat untuk menjawab secara periodik setiap pertanyaan-pertanyaan yang berhubungan dengan bagaimana mereka menggunakan wewenang mereka, kemana sumber daya telah dipergunakan, dan apa yang telah dicapai dengan menggunakan sumber daya tersebut. Guy Peter (2000) menyebutkan adanya 3 tipe akuntabilitas yaitu: (1) akuntabilitas keuangan; (2) akuntabilitas administratif; dan (3) akuntabilitas kebijakan publik. Akuntabilitas publik adalah prinsip yang menjamin bahwa setiap kegiatan penyelenggaraan pemerintahan dapat dipertanggungjawabkan secara terbuka oleh pelaku kepada pihak-pihak yang terkena dampak penerapan kebijakan. Pengambilan keputusan didalam organisasi-organisasi publik melibatkan banyak pihak. Oleh sebab itu wajar apabila rumusan kebijakan merupakan hasil kesepakatan antara warga pemilih (constituency) para pemimpin politik, teknokrat, birokrat atau administrator, serta para pelaksana di lapangan. Dari uraian ini, penulis menegaskan bahwa akuntabilitas itu bukan hanya mengenai tanggung-gugat secara organisasi, yaitu antara bawahan dengan pimpinan organisasi; tetapi yang jauh lebih penting adalah tanggung-gugat kepada rakyat sebagai pemilik dan subyek layanan publik dan pembangunan yang diselenggarakan oleh institusi pemerintah.

Prinsip akuntabilitas publik adalah suatu ukuran yang menunjukkan seberapa besar tingkat kesesuaian penyelenggaraan pelayanan dengan ukuran nilai-nilai atau norma-norma eksternal yang dimiliki oleh para stakeholders yang berkepentingan dengan pelayanan tersebut. Sehubungan dengan hal demikian, maka akuntabilitas itu harus ada pada setiap tahapan sebuah program (kebijakan), termasuk kebijakan penganggaran dan pengalokasian APBD kabupaten. Pertama, tahap proses pembuatan sebuah keputusan, berupa: (1) Pembuatan sebuah keputusan pelayanan harus dibuat secara tertulis dan tersedia bagi setiap warga/masyarakat yang membutuhkan; (2) Pembuatan keputusan telah memenuhi standar etika dan nilai-nilai yang berlaku, artinya sesuai dengan prinsip-prinsip administrasi yang benar maupun nilai-nilai yang berlaku di stakeholders; (3) Adanya kejelasan dari sasaran kebijakan yang diambil, dan sudah sesuai dengan visi dan misi organisasi, serta standar yang berlaku; (4) Adanya mekanisme untuk menjamin bahwa standar telah terpenuhi, dengan konsekuensi mekanisme pertanggungjawaban jika standar tersebut tidak terpenuhi; (5) Konsistensi maupun kelayakan dari target operasional yang telah ditetapkan maupun prioritas dalam mencapai target tersebut. Kedua, tahap sosialisasi keputusan, berupa, (1) Adanya penyebarluasan informasi mengenai suatu keputusan, melalui media massa, media nirmassa, maupun media komunikasi personal; (2) Adanya akurasi dan kelengkapan informasi yang 
berhubungan dengan cara-cara mencapai sasaran suatu program/kegiatan; (3) akses publik pada informasi atas suatu keputusan setelah keputusan dibuat dan mekanisme pengaduan masyarakat; dan (4) ketersediaan sistem informasi manajemen dan monitoring hasil yang telah dicapai oleh pemerintah.

Transparansi adalah prinsip yang menjamin akses atau kebebasan bagi setiap orang untuk memperoleh informasi tentang penyelenggaraan pemerintahan, yakni informasi tentang kebijakan, proses pembuatan dan pelaksanaannya, serta hasil-hasil yang dicapai (Nirwandar, 1997:39). Prinsip ini memiliki 2 aspek, yaitu (1) komunikasi publik oleh pemerintah, dan (2) hak masyarakat terhadap akses informasi. Keduanya akan sangat sulit dilakukan jika pemerintah tidak menangani dengan baik kinerjanya. Manajemen kinerja yang baik adalah titik awal dari transparansi. Karenanya prinsip-prinsip transparasi paling tidak dapat diukur melalui sejumlah indikator seperti : (1) mekanisme yang menjamin sistem keterbukaan dan standarisasi dari semua proses-proses pelayanan publik; (2) mekanisme yang memfasilitasi pertanyaan-pertanyaan publik tentang berbagai kebijakan dan pelayanan publik, maupun prosesproses didalam sektor publik; (3) mekanisme yang memfasilitasi pelaporan maupun penyebaran informasi maupun penyimpangan tindakan aparat publik didalam kegiatan melayani. Keterbukaan pemerintah atas berbagai aspek pelayanan publik, pada akhirnya akan membuat pemerintah menjadi bertanggung gugat kepada semua stakeholders yang berkepentingan dengan proses maupun kegiatan dalam sektor publik. Transparansi akan menjamin semua tindakan yang dilakukan oleh institusi publik menjadi terang dan jelas sehingga dapat dikontrol jalannya oleh publik dan dapat dilakukan perbaikan-perbaikan sedini mungkin jika terdapat kekeliruan (penyimpangan) sebelum terjadinya kegagalan secara menyeluruh.

Partisipasi adalah prinsip bahwa setiap orang memiliki hak untuk terlibat dalam pengambilan keputusan di setiap kegiatan penyelenggaraan pemerintahan. Keterlibatan karena aksesnya memang disediakan (dibukakan) dan dilindungi sehingga ada banyak informasi sebagai pengetahuan yang akan membuka kesadaran masyarakat untuk terlibat secara aktif. Keterlibatan dalam pengambilan keputusan dapat dilakukan secara langsung atau secara tidak langsung. Transparansi bermakna tersedianya informasi yang cukup, akurat dan tepat waktu tentang kebijakan publik, dan proses pembentukannya. Dengan ketersediaan informasi seperti ini masyarakat dapat ikut sekaligus mengawasi sehingga kebijakan publik yang muncul bisa memberikan hasil yang optimal bagi masyarakat serta mencegah terjadinya kecurangan dan manipulasi yang hanya akan menguntungkan salah satu kelompok masyarakat saja secara tidak proporsional. Partisipasi dibutuhkan dalam memperkuat demokrasi, meningkatkan kualitas dan efektivitas layanan publik, dalam mewujudkan kerangka yang cocok bagi partisipasi, perlu dipertimbangkan beberapa aspek, yaitu: (1) partisipasi melalui institusi konstitusional (referendum, voting) dan jaringan civil society (inisiatif asosiasi); (2) partisipasi individu dalam proses pengambilan keputusan, civil society sebagai service provider; (3) lokal kultur pemerintah (misalnya Neighborhood Service Department di USA, atau Better Management Transparent Budget di New Zealand) seperti dilansir oleh Caiden (1996); (4) faktorfaktor lainnya, seperti transparansi, substansi proses terbuka dan konsentrasi pada kompetisi. Kemudian dalam hal penguatan partisipasi publik, beberapa hal yang sebaiknya dilakukan oleh pemerintah adalah: (1) mengeluarkan informasi yang dapat diakses oleh publik; (2) menyelenggarakan proses konsultasi untuk menggali dan mengumpulkan masukan-masukan dari stakeholders termasuk aktivitas warga Negara dalam kegiatan publik; (3) mendelegasikan otoritas tertentu kepada pengguna jasa layanan publik seperti proses perencanaan dan penyediaan panduan bagi kegiatan masyarakat dan layanan publik; dan bahkan yang paling ditunggu-tunggu (4) pemerintah harus membuat terobosanterobosan baru melalui komitmen politik untuk membuat produk-produk kebijakan yang menjadi dasar legal formal penerapan prinsip-prinsip good governance dan perlindungan hak-hak warga (rakyat).

\section{Simpulan dan Saran}

Dalam rangka mencapai good governance, guna menuju kinerja pemerintahan yang tinggi, maka 3 pilar good governance: akuntabilitas, transparansi, dan partisipasi haruslah diimplementasikan dengan baik melalui tindakan nyata dalam bentuk revitalisasi, yaitu penginjeksian nilai-nilai good governance dalam praktek-praktek penyelenggaraan urusan (manajemen) publik dengan landasan legal formal nyata.

Akuntabilitas merupakan prinsip yang menekankan pada kemampuan menjawab (answerability) dan konsekuensi (consequences) atas penyelenggaraan kepemerintahan sebagai sebuah respon pemerintah secara periodik atas setiap pertanyaan-pertanyaan (keluhan) publik dan konsekuensi yang harus diterima oleh aparatur publik ke depan sebagai tindakan tanggung-gugat peningkatan kualitas pelayanan publik. Transparansi adalah prinsip yang menjamin akses atau kebebasan bagi setiap orang untuk memperoleh informasi tentang penyelenggaraan 
pemerintahan. Informasi mengenai proses pembuatan dan pelaksanaan program (kebijakan) serta hasil-hasil yang dicapai. Prinsip ini menekankan aspek: komunikasi publik oleh pemerintah dan hak masyarakat terhadap akses informasi. Dengan keterbukaan pemerintah atas berbagai aspek pelayanan publik, maka akan membuat pemerintah menjadi bertanggung gugat kepada semua stakeholders yang berkepentingan dengan proses maupun pelaksanaan program (kebijakan) sektor publik. Sementara prinsip terakhir adalah partisipasi. Partisipasi menekankan bahwa setiap orang memiliki hak untuk terlibat dalam pengambilan keputusan di setiap kegiatan penyelenggaraan pemerintahan. Keterlibatan secara aktif akan menjadi media interaksi dan kerjasama yang baik, sharing informasi dan pengalaman antara pemerintah dengan semua komponen stakeholders-nya dalam pengambilan keputusan, baik yang dilakukan secara langsung (keterlibatan individu) atau secara tidak langsung, yaitu melalui representasi kolektif seperti LMS, lembaga adat, kelompok kepentingan dan infrastruktur sosial politik yang lainnya.

\section{DAFTAR PUSTAKA}

Agere, S. (2000). Promoting Good Governance. Commonwealth Secretariat Marlborough House Pall Mall, London,

Caiden, G.E. (1996). The Future of Public Administrations in Public Adminis-trations Under Scrutiny, Canberra: Centre For Research in Public Sector Management University of Canberra, Institute of Public Administration Aus-tralia,

Dwiyanto, A. (2003). Reformasi Tata Pemerintahan dan Otonomi Daerah di Indonesia. Yogyakarta: Pusat Studi Kependudukan dan Kebijakan, Universitas Gadjah Mada.

Dwiyanto, A. (2003). Teladan dan Pantangan Dalam Penyelenggaraan Pemerintah dan Otonomi Daerah. Yogyakarta: Studi Kependudukan dan Kebijakan, Universitas Gadjah Mada.

Frederickson, H. G. (1997). The Spirit of Public Administration. San Francisco; J ossey-Bass Publisher.

J uwana, H. (2006). Paper: Politik Hukum UU Bidang Ekonomi di Indonesia, MPKP, FE.UI .

Lane, J.E. (1995). The Public Sector: Concepts,
Models and Approaches. London: Sage Publications.

Marschall, M. (1999). From States to People: Civil Society and Its Role in Gover-nance in Mbogori, Ezra, (Ed) CM I Society at the Millennium. West Hartford: Kumarian Press, pp. 167-178.

Muhardi. (2005). Paradigma Boros Dalam Kegiatan Ekonomi dalam Mimbar, Jurnal Sosial dan Pembangunan, Vol. 21 No 1.B andung: Pusat Penerbitan Universitas (P2U)-LPPM Universitas Islam Bandung.

Newland, C.A. (1997). Realism and Public Administration, Public Administration Review, Vol. 57 Number 2.

Nirwandar, S. (1997). Birokrasi di Indonesia. Jakarta: Bandiklat Depdagri.

Surkati, A. (2012). Otonomi Daerah Sebagai Instrumen Pertumbuhan Kesejahteraan dan Peningkatan Kerjasama Antar Daerah dalam Mimbar, J urnal Sosial dan Pembangunan, Vol. 28 No 1. Bandung: Pusat Penerbitan Universitas (P2U)-LPPM Universitas Islam Bandung.

Undang-Undang Nomor 28 Tahun 1999 tentang Penyelenggaraan Negara yang Bersih dan Bebas dari Korupsi, Kolusi dan Nepotisme.

Undang-Undang Nomor 31 Tahun 1999 tentang Pemberantasan Tmdak Pidana Korupsi.

Undang-undang Nomor 17 Tahun 2003 tentang Keuangan Negara.

Undang-undang Nomor 1 Tahun 2004 tentang Perbendaharaan Negara.

Undang-undang Nomor 15 Tahun 2004 tentang Pemeriksaan Pengelolaan dan Tanggung Jawab Keuangan Negara.

Undang-Undang No 25 Tahun 2004 tentang Sistem Perencanaan Pembangunan Nasional.

Undang-undang Republik Indonesia Nomor 32 Tahun 2004 tentang Pemerintah Daerah.

Undang-undang Republik Indonesia Nomor 33 Tahun 2004 tentang Perimbangan Keuangan Pusat dan Daerah.

World Bank. (1989). Strengthening Local Government in Sub-Saharan Africa, EDI Policy Seminar Report No. 21, Washington DC.

World Bank. (1992). Governance and Development, Washington, D.C. 